\title{
Symposium Review of
}

\section{The Amish \\ by Donald Kraybill, Karen Johnson-Weiner, and Steven Nolt}

\section{Overview}

The Amish is a 500-some page university press-sized handbook that touches on a variety of topical areas. The book is the culmination of two and a half decades each of Kraybill's, Johnson-Weiner's, and Nolt's work about the Amish. Karen Johnson-Weiner published a series of linguistic studies through the 1990s, and from these spring-board works later explored more fully schools and New York settlements. Donald Kraybill's first Amish-focused publication was a Durkheimian study of the Amish and suicide in 1986. From then on he has maintained this functionalist orientation in comparative studies of plain Anabaptists and Amish responses to cultural, economic, and political change. Steven Nolt's work follows two threads: Amish history, of which his A History of the Amish (1992) stands as the premiere testament, and Amish identity, realized most fully in Plain Diversity (2007), co-authored with Thomas Meyers. While Kraybill and Nolt have collaborated on seven publications, this is Johnson-Weiner's first publication with either.

Given the book's volumous size and its claim to be the first generalist book about the Amish since John Hostetler's first edition of Amish Society (1963), we as co-editors felt the book merited special review via a symposium in JAPAS. Three respondents provide reviews: a scholar of the Amish, a scholar outside Amish studies, and an Amishman. The first is Steven Reschly, a JAPAS editorial board member whose research focuses on Midwestern Amish and Amish from around the 1870s to 1930s. His work extends Bourdieau's theories by arguning for a communitybased Amish repetoire of action. The second reviewer is Benjamin Zeller, who has published several books about New Religious Movements and religion \& food. He is Assistant Professor of Religion at Lake Forest College. The third reviewer is Tom Coletti, a long-term convert to the Amish and a farmer in the Union Grove, NC, community. Megan Bogden, a former student in Ohio State University’s Amish Society course, provides a brief book summary.

—Cory Anderson, co-editor

Bogden, Megan, Steven Reschly, Benjamin Zeller, Tom Coletti, Donald Kraybill, Karen Johnson-Weiner, and Steven Nolt. 2014. “The Amish Symposium.” Journal of Amish and Plain Anabaptist Studies 2(2):278-302. 


\section{A Synopsis of The Amish}

Megan Bogden

Student

The Ohio State University

Chapter one summarizes the book and lays a foundation for interpreting the Amish. The Amish are divided into church districts and settlements that vary from state to state. This organizational breadth results in varying standards and regulations. Based on their society's structure, "the Amish resemble an ethno-religious community more than a denomination" (5). Amish apparent rejection of "modernity," a theory used to interpret the Amish experience throughout the book, is emphasized not so much as a preference to live in the past as an attitude of self-denial. Amish settlements, despite slight differences from one to the other, have ten common values they uphold, which are listed. Their cultural identity does not come from a set of traits but rather from oral tradition and the sum of the group, constituting the deeper whole of who the Amish are today.

Chapter two addresses Amish history. As Protestant reformers challenged church doctrine, "the stage for a more radical reform was set" (23). The beginning of the sixteenth century birthed a group of Germanic radicals who disputed the church-state relationship. This group based their beliefs upon the teachings of Jesus and that following Him trumped all else. One principal, controversial belief they upheld was the baptism of adults rather than infants. Therefore, they became known as "Anabaptists.” Oppression and persecution followed the Anabaptists. This persecution continues to be “a focal point of Amish consciousness” (24). The Martyrs' Mirror, a book recounting stories of persecutions and executions, is commonly found in Amish homes today. Additionally, genealogy books are commonplace as well as family trees adorning their household walls. For the Amish, knowing and remembering their roots is important.

Eventually, the Anabaptists were concentrated in the Rhine and Alpine valleys but they were not welcomed by all. Concurrently, their denomination was in flux. Jakob Amman emphasized a greater set-apartness. Amman formed another community that adhered to stricter codes of conduct, especially in dress, lifestyle, and interaction with outsiders. Eventually, the group took on the name "Amish." When the opportunity to immigrate to America arose, the Amish took it and continue to grow in America today.

Between 1736 and 1770, around 500 Amish moved from Switzerland and Germany into Southeastern Pennsylvania. Amish were searching for freedom and opportunity. When they arrived, they found everything they wanted, and in abundance. Yet, the Amish were faced with the challenge of church responsibilities and upholding former practices. They found that with opportunity also came the abandonment of simplicity and a new fascination with material things. Despite the world around them scurrying to buy the newest, biggest, best thing, they worked to 
maintain the lifestyle they had fought so hard to have. This challenge brought forth the Ordnung.

The Ordnung is specific to a settlement or church district and can vary from place to place. The German word meaning “order” is in essence the rulebook (albeit orally established) that the community relies on to know what is and is not acceptable. Reestablishing themselves in America was a challenge of its own given members' differing opinions and opposition of the government. Even today, some communities are orthodox, some are contemporary, and some fall in the middle. Struggles remain today between the Amish and the state, as with taxes, schooling, and horse and buggy transportation. The Amish are living among a people that prioritize values differently.

Amish communities are primarily a religion. The church is the nucleus of the community, though "the religious ideals and the social system reinforce each other" (60). Rather than interpreting the Bible and developing new interpretations, the Amish believe that the Bible can “interpret itself” (60). When they pray, they use the Lord's Prayer and little else. They believe that Jesus already gave a prayer to pray, and nothing can improve on what he provided. Also, to produce a different prayer would be viewed as proud. Their church services are based upon the Ausbund and the Eighteen Articles of Faith. Both of these works are rooted in past generations, therefore connecting the church members to their roots. Above all other responsibilities, the church stresses discipleship and obedience. Self-denial is practiced across all Amish groups. Amish successfully practicing self-denial are seen as the "most devoted, sincere, and useful Christians" (64). Gelassenheit, or "yielding” as a rough English translation, is the glue that holds every community together. Gelassenheit is submission to God and to others and is exemplified in the communal structure of Amish society. This characteristic interweaves through all other facets of Amish society, holding it together. By serving others, everyone will be cared for. There is no competition or pride inhibiting productivity or detracting them from focusing on God. Simplicity, yieldedness, obedience, and self-denial are all part of "The Amish Way" which is rooted in the church's values.

Social organization is also rooted in Gelassenheit. Amish feel an obligation to help each other, even across differing Ordnung lines. The differentiation between groups across America can be moderate to extreme but it is all the result of disagreement. When orthodoxy is thrown out the window and pride or desire for technology steps in, a new community is formed. Not always do new groups arise out of animosity or negative reactions, but typically a split does occur. Depending upon whether the community identifies as New Order, Old Order, Swartzentruber, or another group, differences are evident from dress to how their buggies are built and even in their growth rate. A table in The Amish displays the growth of different communities in the past twelve years, showing that the Swartzentruber community, with its ultra-orthodox Ordnung, has the highest growth rate (153). The authors conjecture that this growth is attributed to the isolation of the community and minimal urban influence.

Despite the expectations of many, the Amish population continues to grow exponentially, 
which is attributed to large families. Large families are justified through the Biblical command to "be fruitful and multiply” (Genesis 1:28). A settlement's location can also affect family size. In more developed settings, families are smaller since not as many hands are needed to help with farm work. The communities acquire few converts. Leaving the church and the community is not common. During Rumspringa, the "running around” time, teenagers must decide whether or not to join the community through baptism or pursue life outside the Amish. Because of peer pressure and upbringing, leaving is atypical, although it happens.

Gender roles are based upon trades in the community. Women and men have specific roles to fill. Men and women are seen as different, though not necessarily better or worse than the other. The men are the head of the household, as it is patriarchal, and the women work alongside but have the responsibilities of raising the children and caring for the home. Shifts in responsibility occur across life stages: infancy, early childhood, school age, adolescence, adulthood, and old age.

As infants are seen as gifts from God, they are cherished; “all ages delight [in them]” (195). As they grow into early childhood, they learn quickly that they, too, like others, have responsibilities. At this point in the child's life, the parents give the care and education necessary to be successful in Amish life. The child's duty is to learn obedience. When they become school age, they learn life skills necessary to succeed. In school, they start socializing and bonding with others across the community. At home, they learn responsibilities that will soon be theirs, as a mother or father, husband or wife. The adolescent period is between fourteen and sixteen. This is when they begin assuming adult roles, but they do not yet have the responsibility of that role. Also, at this point, they identify with their peers more than ever before. Rumspringa is the bridge from adolescence to adulthood. At this time, adolescents discover who they are in the community, where they stand with their faith, and who their future mate may be. Adulthood comes after a couple marries, usually after baptism (signifying church membership). This is the stage where gender roles are completely realized and each is actively acting in them. Ultimately, the husband is placed as the head of the household, meaning he is completely responsible for the spiritual and physical well being of his family. The Amish believe that marriage is a partnership between a man and a woman. By subjugating the woman, it is by no means demeaning her; those are simply the roles. Finally, when a married couple reaches the age where they have no children to care for, they go to live with one of their married children; more often than not they sell their businesses and go about life just as they did in the roles with which they identify.

Young adults experience a rite of passage into adulthood called Rumspringa. This limbo period is between age sixteen (or seventeen in more conservative groups) and when they join the church. Depending on the settlement and the degree of orthodoxy, Rumspringa can be as innocent as wearing fashionable clothing or as serious as developing a drug or alcohol addiction, but in no way is it possible to generalize and say that all youth choose to do the same thing. As they begin preparing for the lifelong commitments_-baptism and marriage — they are beginning their Amish lives. 
The Amish relationship with farming and the land is seen as a responsibility and a connection to God. Farming is revered as such because farmers are a part of the cycle of life and death and the renewal that God offers. Amish farming periods are divided into three: pre-1950, 1950-2000, and the early twenty-first century. Before 1950, the methods and work were "modest and diversified." In their chores, they used hand tools with the help of animals. Preceding 1950, specifically before 1900, Amish farming technology paralleled that of the English. In some instances, Amish employed state of the art machinery, as differences in agricultural technology did not encompass Amish identity until the early 1900s.

Between 1950 and 2000, American agriculture grew to a “corporate scale,” making competition for Amish farmers stiff. These circumstances stressed the Ordnung. How could the Amish adapt and thrive without compromising values and traditions? More traditional groups held to the small family farm. Others converted farm machinery to boost production yet kept within the Ordnung bounds. In the early twenty-first century, similar challenges remain, although, now the controversy is about finding employment away from the farm. The lack of land and rising prices of available land, as well as the rising population, has made it difficult for the Amish to continue the path of their ancestors. To continue this tradition rooted in agriculture, settlements are finding new ways to adapt and survive. Working off the farm has led to entrepreneurship that has created new community tension. One of the main problems is the fear of losing family cohesion. Other problems arise through legal codes.

The authors write that "Limits on technology are the signature mark of twenty-first century Amish identity.” Yet, contrary to popular opinion, the Amish are not opposed to technology; they simply prohibit certain types. The Amish rely heavily on their Gmay to dictate the decisions on acceptable technology. Decisions are based on the effects of new technology on the community. If they identify negative effects toward community cohesion or religion, they abstain. They do not see technology as inherently bad, rather a distraction or temptation. The authors identify five ways in which Amish communities deal with technology: rejection, acceptance, adaptation, invention, and distinction between ownership and access. These five filters determine the place of technology in a community. This chapter includes examples to show Amish attitudes toward some technologies.

In the chapter Health and Healing, the authors remind us that the Amish only attend school up to eighth grade. Hence, their practices range from self-dentistry to regular formal check-ups to only seeing an unlicensed Amish doctor. Whatever the choice, health practices are determined not by the Ordnung or the Gmay but rather family tradition. Four resources available to them: folk, alternative, standard, and church-community. These range from using self-taught Amishmen to visiting high-tech hospitals for surgery and then receiving encouragement in the form of visits and donations. Two major issues are immunizing and birthing. Both can be understood in light of how Amish use the Bible. Immunizations show distrust in God and birthing is meant to be had at home with the family there for support. The last thing mentioned is the genealogical history that this culture holds. Since they are so close-knit and have been around 
for centuries, their roots are traceable back to multiple continents and areas.

The relationship between the Amish and the government is strained. Being a nonbureaucratic people, they keep to themselves and the government does likewise. As with other life domains, Gelassenheit is a concrete principle that they uphold with the government just as they do everything else. When conflicts arise with the government over schooling, taxes, or military service, the Amish react in a peaceful way. They do not make use of the legal system and do their best to negotiate things quietly as to not bring attention to themselves.

As far as writing and publishing, the Amish read and write much, but internally. They write religious works that emphasize the importance of the Ausbund, school books that their children use, and works that encourage their family values and trust in God. They recognize a few secular authors but not many.

Tourism and media paints a romantic picture of the beautiful Amish countryside where one can relax and "get away from it all.” The tourism industry generates much income for Amish communities but it incorrectly portrays Amish culture.

The final section of The Amish describes the adaptations the authors believe the Amish will make in the future to still be separate themselves from the English world, but also adapt to the world that surrounds them. Just as they have adapted, survived, and thrived in the world today, they will also do so in the future. 


\section{Review of The Amish by a Scholar of the Amish}

Steven D. Reschly

Professor

Department of History

Truman State University

The Amish is a state-of-the-art compilation of information about the spectrum of Amish affiliations gathered across many years by many scholars and authors. The sheer amount of knowledge in this 500-page book is overwhelming, and the book is far superior to the PBS documentary in the "American Experience" series for which this book is intended as a companion. Kraybill is a sociologist, Johnson-Weiner an anthropologist, and Nolt an historian. Together, they discuss nearly every matter that appears in recent scholarly and popular literature: diversity, the shift from farming to wage labor and small business, religious rituals and symbols, relationship and conflicts with the modern nation-state, demographics, education, Rumspringa and retention rates of young adults, gender and family, tourism, technology, medicine, and the list continues. They are usually careful to define which Amish group is under discussion, because all these matters vary by location and affiliation. The volume will serve as a useful encyclopedic compendium of research on the Amish as it stood in 2013.

I have reviewed many books on the Amish during the past 25 years. The weaknesses that are almost always present are also present in this volume, albeit to varying degrees. The first problem is the historical background, most often the first chapter of a book. It is treated as a throwaway chapter required by the editor or publisher before the author can get to the real "meat" of the subject at hand. The story is an internal one, of heroic Swiss and South German Anabaptists persecuted by Reformation-era state churches, led by coercion or choice to settle further down the Rhine valley in Alsace or other more tolerant regions. From these scattered Swiss Brethren arose in the late seventeenth century a renewal movement led by Jakob Amman (originated by the itinerant preaching of Ulrich Müller in the Swiss Oberland, if Leroy Beachy is correct), which resulted in a division as Amish and Mennonites went their separate ways. There is little attempt to engage the vast changes wrought by scholars of the sixteenth century during the past several decades. In fact, it is hardly accurate to name the period "The Reformation Era" any longer, so profoundly has the scholarly landscape shifted. The example of French scholar Jean Séguy, who traced the impact of the French Revolution with its new concepts of nation-state citizenship within the broader Age of Democratic Revolution to Anabaptist farmers in what is now northeastern France, has unfortunately not been followed. There are marvelous new books by German scholar Frank Konersmann that include references to eighteenth-century Mennonite farmer David Möllinger and his influence on the early modern agricultural revolution in the Palatinate region, which also involved Amish renters of farm estates, but this material is absent from The Amish. 
If general European history is missing from most studies of the Amish, so also is general North American history, except where this history impinges directly on Amish communities: wars, consolidated schools, food production regulations, the welfare state, and so forth. Paton Yoder, in Tradition and Transition, at least attempted to relate Amish migration westward to general American migration that followed the displacement of Native Americans. He also had to deal, to some extent, with the Civil War since the mid-century Diener Versammlungen minutes raised questions about Amish men buying military substitutes or paying commutation fees. The revolutions in social history and cultural history have exerted very little impact on Amish scholarship. It is a problem in general in religious studies; the histories are internal with very little reference to wider historical contexts. The Amish movement away from farming and into small businesses and wage labor could have interesting connections, for example, with the deindustrialization of the Rust Belt and the depopulation of rural America in general. The reality TV obsession with the Amish and Rumspringa could usefully be related to postmodern media developments and temporary celebrity for celebrity's sake. Are Amish teenagers like the Kardashians? The Amish could be placed in world history in terms of power and trade relations, the global reach of American military forces, and the recalcitrant issues of third-world development. Limiting the story, most of the time, to an internal narrative deletes much potential for a richer and more complex storyline involving global climate change, energy politics, and many other issues.

My second standard problem while reviewing books about the Amish is the absence of theory. The book under review does more with theory than most recent books, partly by borrowing theoretical models used by Susan Trollinger in her book on Amish tourism in Ohio and by Valerie Weaver-Zercher in her book on Amish romance novels. There are fleeting references to sociologist Zygmunt Bauman's “Liquid Modernity,” and to French philosopher Gilles Lipovetsky’s "Hypermodernity” (10-11), but these promising terms are not used in the rest of the book. "Boundary maintenance" has virtually disappeared, thankfully, as it was most often used to avoid any engagement with social or cultural theory. It was considered self-evident, not needing explanation.

The dominant paradigm, however, remains “negotiating with modernity.” This phrase usually sounds like "war on terror" to me, a verb followed by an abstraction, or a verb with no object. The phrase is described on page 9 in clearer and more precise terms than I have seen elsewhere: “social bargaining” as a "dynamic process,” with “cultural bargaining” and "structural bargaining” as component parts. Still, there are two main problems with this phrase. "Negotiating” and "bargaining” seem too self-conscious and calculating for the intuitive, trialand-error, conscious unselfconsciousness ways in which each local community develops its Ordnung over time. It is not like negotiating a peace treaty between warring nations, or a labor contract between workers and management. The other problem is the very term "modernity," especially any use of "modernization" as a master grand narrative or as a category of historical analysis. Modernization theory has been excoriated by numerous post-colonial scholars for its 
Western colonial bias and its linear model of social and economic development. Modernization is nearly an unusable word in polite scholarly company. "Negotiating with modernity" is not a satisfying analytical metaphor.

The greater problem is, I have no alternative to suggest. I used habitus in my dissertation and first book, The Amish on the Iowa Prairie, 1840-1910 (2000), borrowed from French sociologist and social theorist Pierre Bourdieu, but the term is likely too obscure for widespread use in Amish literature. The authors acknowledge habitus on page 433, footnote 3 . The term is difficult to understand in isolation from the rest of Bourdieu's writings, where habitus (the internal) is always paired with "field" (the external), which are mutually influential. Bourdieu is far less well-known in the United States than he should be, and far less well-known than his contemporaries, Michel Foucault and Jacques Derrida. The Ordnung process may turn out to be one of those phenomena that are impossible to explain, but if one understands it or has experienced it, no explanation is required. There is an interesting paragraph on page 333, following a long quote about evaluating change from an Amish writer, which begins with "This strategic, rational, forward-looking analysis” of technology shows that the Amish are intentional in thinking about technology, and ends with the observation about how the Amish evaluate the impact of technology: "they sense it intuitively.” I confess my bewilderment, and predict that "negotiation" and "bargaining" will continue to be used to describe how the Amish deal with the economic, political, technological, and social changes happening around them, until someone comes up with something better.

My third problem is the lack of engagement with the wider world of scholarship. This is a general problem in religious studies, which tend to be written in splendid isolation from other disciplines. To choose only one example, immigration history has grown far beyond its roots in filiopietistic, uncritical accounts of immigrant communities within the United States to the study of migration in world history. Scholars discuss sending and receiving zones, patterns of movement by coercion or choice, and the complexities of identity formation in multiethnic contexts. This literature could contribute much to the hows and whys of the Amish diaspora. The works of Royden Loewen with Kleine Gemeinde Mennonite communities would serve as examples of the potential influence of recent trends in migration studies. There is little attention paid to the development of historiographies in women's history, labor history, international geopolitical history, and the list could continue. The tragedy here is that Amish Studies could contribute much to these broader scholarly disciplines, but seems preoccupied with insulated and isolated anthropological description and sociological statistics.

Variations of one or more of these three points are ones I almost always make in reviews of books about the Amish. It seems grossly unfair to ask the authors of a 500-page book to do even more, and The Amish remains an excellent summary of current research and writing on the Amish. In scope and thoroughness, it will be difficult to match. My hope is that scholars will utilize this wealth of information to develop further studies in the directions I have suggested, and thus enrich this field even further. 


\section{Review of The Amish by a Scholar outside Amish Studies}

Benjamin E. Zeller

Assistant Professor

Department of Religion

Lake Forest College

\section{The Amish, The Amish, and the Study of Alternative Religiosity in America}

\section{The Amish \& The Amish}

I suspect that most Americans have encountered the Amish at best through quilts and cheese, and at worst through the reality television series Breaking Amish or Weird Al Yankovic's musical parody “Amish Paradise.” Most outsiders who have encountered the Amish through popular or consumer culture likely do not stop to consider the religious practices, beliefs, worldviews, or history that have shaped the contemporary Amish. Public Broadcasting's (PBS) American Experience: The Amish and Donald B. Kraybill, Karen M. Johnson-Weiner, and Steven M. Nolt's book, The Amish, aim to rectify that.

Billing itself as a "companion to the PBS American Experience series," this book is really much more than that. It covers history, Amish culture, internal social structure, and a range of social-cultural linkages between the Amish and outsiders. Readers unfamiliar with the Amish will find this book to be an immense trove of new ideas about this often stereotyped group. Although I had encountered the Amish in my studies of the radical reformation as well as my work on new and alternative religions in America, I learned a lot. The authors should be commended for the level of detail in this book, both in terms of contents and how they were treated. To offer only a few examples:

Cultural manifestations of Amish religiosity received ample treatment in this book, with the authors detailing how the Amish live, work, play, and pray. The book interweaves the big picture and highly technical details. To take one case, the authors detail how and why the Ordnung (the unwritten rules of Amish living) in various Amish communities leads adherents to eschew the connection of their homes or businesses to the national electrical power grid, and how electricity and its generation become moral issues for the Amish. That is the big picture. But the book also provides details such as how Amish make use of diesel generators to power air pumps and batteries for household and business appliances (including a highly helpful technical chart!), and various debates between different Amish groups about precise methods of power generation and use. The takeaway here for readers is that broad generalizations such as "the Amish do not use electricity” must be broken down and assessed from multiple angles, bearing in mind internal diversity among the Amish.

Another example of the authors’ scholarly acumen relates to their careful and judicious 
use and study of language. The authors make careful note of how and when Amish switch between languages - Pennsylvania Dutch, German, Swiss German, and English—again with attention to distinctions between different Amish groups, social circumstances, and styles of worship. In their own use of language, while all terms are translated into English, the authors also provide the proper names of various concepts in German or Pennsylvania Dutch. In one instance - the authors' analysis of Amish liturgy - they include both the original German and an English translation of Das Loblied, what they refer to as "an Amish anthem of sorts," and a careful explanation and analysis of its themes (82-3). While the English is of course helpful for the general reader, scholars will appreciate being able to read the hymn in its original on the opposite page. (Admittedly, most of us will find the Fraktur script more difficult to decipher than the actual language!)

All this is to say that The Amish is a major contribution to the study of this religious movement, and that scholars will look to Kraybill, Johnson-Weiner, and Nolt's book and its encyclopedic treatment of the subject as a go-to volume on the Amish. In belongs on the same shelf as Stephen J. Stein's The Shaker Experience in America and Jan Shipps's Mormonism in terms of being the standard monographic treatment of an iconic alternative religious group in America. But I have been asked in this venue not to comment only on the book, but to reflect how it relates to my own academic subfield, that is the study of new and alternative religions. To that I now turn.

\section{Alternative Religiosity}

Those of us who study new and alternative religions have multiple ways of defining and delineating our constituent terms - i.e., "new religious movements” (NRMs) and "alternative religions.” In terms of newness, most scholars of NRMs hinge our definition on a group being founded within the past few generations, or even more importantly most of the members being first generation converts. In terms of alternativeness, we emphasize differences from or even tensions with broader culture. Those of us in the subfield readily admit to some sloppiness here: when does a group become too old to be new? How does one begin to decide what counts as "mainstream"? Regardless, movements wherein the majority of members are either coverts or the children of converts, and that hold themselves in opposition to mainstream culture are the bread and butter of my academic subfield and specialty.

From one perspective, the Amish therefore seem rather far afield, and to me an odd choice for a commentator on The Amish. Amish groups trace their origins to the seventeenth century, and few Amish are converts or even the children or grandchildren of converts. (The authors note that the Amish have received and retained only 75 converts in the past 60 years! [pg. 159]) In terms of alternativeness, indeed the Amish are "alternative" to mainstream culture, but in a highly traditionalist manner that we seldom associate with new and alternative religiosity. Then what am I doing writing this essay? 
Yet from my perspective, scholars of new and alternative religions focus on groups that have a lot in common with the Amish. While the Amish are not new and few members are converts properly speaking, all made the choice implicitly or explicitly to live within a group outside the bounds of normative American religion. All Amish-and for that matter, all Anabaptists - have opted in, and therefore this parallels the membership of other alternative or new religions. In terms of Amish traditionalism, in fact many of the most notable new religions of the past two centuries have claimed to merely be restoring proper tradition, whether that be ancient Vedic norms (the Hare Krishnas), early Christianity (Children of God / The Family), or prehistoric matrilineal nature traditions (Wicca / Neo-Paganism). In fact, the Amish and The Amish are quite relevant for those of us who study new and alternative religions in America, and the Amish are birds of a feather with many of the new and alternative religions of the past halfcentury.

This book therefore tells a story that scholars of NRMs will recognize. In their history of the origins of the Amish, the authors trace the same sort of forces at work in the emergence of new religions today. This includes charismatic leaders, internal disagreement, and institutionalization. Most crucially, it is a story of the creation and maintenance of an alternative religious subculture whose adherents explicitly envision themselves as living in opposition to mainstream American society ("the English," in Amish parlance), and who have adopted elements of anti-modern and anti-industrial living in an attempt to insulate themselves from what twentieth century social commentator Walter Lippmann called the “acids of modernity” eating away at tradition, religion, and society.

Kraybill, Johnson-Weiner, and Nolt write compellingly that, “[d]espite the social and technological upheavals that have accompanied the twentieth century, the Amish, with their emphasis on separation from the world and their penchant for traditional ways, have thrived" (155). I would argue that, especially with reference to what scholars have seen among new and alternative religions in the late twentieth and early twenty-first centuries, the Amish have thrived not despite technological and social changes and their rejection of them, but because of them. While social, cultural, and technological change have been continuous throughout human history, the past 150 years have seen tremendous and unparalleled changes on economic, technological, industrial, and cultural levels. Urbanization, mechanization, higher education, modern science, changing gender norms, and mass media represent only a few of such changes.

Alternative religious groups thrive by positioning themselves in opposition to some or all of these changes. As George D. Chryssides and I (2014) have argued in our study of new religions of the late twentieth century, adherents generally reject major components of modernity. New religions offer alternative visions of what it means to be human, live and work in a meaningful community, and belong to a social group. These range from utopian projects such as The Farm and its retreat to premodern agriculture and imagined social norms of a simpler era, to the Twelve Tribes and its wholesale attempt to recreate first century Christian religious and cultural norms in the American countryside. Some new religions look to India or Japan for 
guidance, such as Transcendental Meditation with its attempts to create an ancient Indian (Vedic) community in the middle of Iowa. All of this parallels the Amish quest to create a pure alternative to modern America and a culture harmonious with what they envision as divine sanction.

To be sure, there are new and alternative religions that embrace modernity, such as Scientology, the Raelians, or Heaven's Gate, all of which look to science and modern technology as panaceas. Yet even these groups envision something wrong with contemporary mainstream culture, and they generally point to the hallmarks of modernity-bureaucratization, rationalization, and individualization, among others - as objectionable. In creating alternative visions of how to live, even these "forward-looking" new religions parallel the Amish project of creating communities inoculated against the worst of the acids of modernity.

\section{Community and Culture}

Within the context of that anti-modernity, it is the centrality of community and yearning for that community that most forcefully emerge from Kraybill, Johnson-Weiner, and Nolt's book. "Unlike modern modes of spirituality that see the spiritual quest as mostly private, the Amish fuse personal faith and communal commitments," they write (64). Time and again the authors harp on the centrality of the ideal of community within the Amish religious ethos and the culture that emerges from it. One finds this in everything from Amish worship patterns (in houses, sitting by age and gender rather than family units), to their method of selecting leaders (nomination and then by lots), to rituals of conformity such as public confession and even the Bann (shunning).

It is clear based on the authors' treatment that Amish communities envision themselves as alternative to mainstream English culture and in needs of defense against it, as evidenced by the rejection of telecommunication technology, mainstream forms of entertainment, and other forms of access. Even more so however, the Amish communities form their own subcultures, distinct from and in opposition to the mainstream. As noted, one finds this in worship and church leadership certainly, but The Amish also notes the development of such a subculture in child rearing, crafts, language, dress, and the engagement with material objects. In all of these cases, Amish creatively attempt to manage their engagement with outside modernity. The authors' treatment of how otherwise forbidden objects can become "Amishized" (117) is an excellent example of both the interplay of theology and practice in daily life, as well as their attention to material culture.

As a religious subculture based on the notion of Gelassenheit- “calmness, acceptance, and yieldedness," as the authors translate it-Amish culture "stands in stark contrast to the bold, assertive individualism of mainstream-culture” (98-100). Here again one sees how the authors emphasize the oppositional quality of Amish culture. This certainly parallels what one finds in new and alternative religious movements with their unique styles of dress, childrearing, sexual 
mores, food, worship patterns, and approaches to such American mainstays as work, family, and leisure. The Hare Krishnas certainly do not share much in common with the Amish on a cultural or theological level, but socially they function analogously as oppositional subcultures.

Kraybill, Johnson-Weiner, and Nolt's treatment of the Amish religious culture as oppositional and subcultural raises for me the issue of the definition and maintenance of the concepts of fringe and mainstream, both among the practitioners we study as well as among academics. To borrow a concept from anthropology, there exists here an overlap: the Amish and other alternative religious practitioners do indeed envision themselves as alternative-making it an emic concept - but we as scholars also use the same distinction in our etic analysis. I wonder if we mean the same thing by our various constructions of alternativeness? The strategic engagement of the Amish with particular forms of American culture, and the strategic rejection of other aspects, marks Amish groups as well as other new religious movements as remarkably astute in their engagement with the "mainstream.” Amish use of solar panels or Natureworshipping Pagans congregating on the Internet both indicate that these "alternative" religions and their supposed opposition to modernity are not always so clear-cut.

The authors point out that the Amish story is "deeply entwined with the American saga" (38). This is a reality that speaks also to new religious movements broadly, and challenges us to reconsider the alternative / mainstream distinction that we often assume not just in the study of new and alternative religion, but also in broader American religious history. R. Laurence Moore's Religious Outsiders and the Making of Americans is nearly thirty years old, but his argument that outsiders have fundamentally shaped American religiosity, and that to be an outsider is in some ways quintessentially American, seems just as apt today. At times therefore the language of "alternative" seems to hide more than it reveals. One example is the relation of family size to the relative religious conservatism of different Amish communities. The authors of The Amish rightly point out that the more conservative an Amish group, the more likely they will have larger families, with more traditional Amish communities having more children on average per family. The authors even cite "an esteemed Amish leader" who cites Psalm 127, "happy is the man that has a quiver full of them [i.e., children].” Here this esteemed Amish man might well have been speaking for a significant subculture within Evangelical Christianity that holds an identical position, even taking the name "Quiverfull” as a moniker for itself. While not necessarily quoting the same Biblical verse, Latter-day Saints (Mormons), conservative Catholics, Haredi (Ultra-Orthodox) Jews, and other conservative groups would make the same claim. At some point all these subcultures or alternative cultures add up, and one wonders where the "mainstream” is!

\section{Conclusion}

Kraybill, Johnson-Weiner, and Nolt's The Amish raises a number of pertinent issues to scholars of new and alternative religions. The question of the relationship between Amish culture and broader American culture is an especially acute one. But more broadly, the authors' focus on 
the culture of the Amish reminds us that with a few notable exceptions such as the Shakers, we have far too often neglected the study of that culture-as opposed to theology, social elements, texts, or history — of new and alternative religious movements. Kraybill, Johnson-Weiner, and Nolt's careful documentation and analysis of socialization, retention, and defection, and the place of gender within Amish culture are all of direct relevance for those of us who study new religions. On a darker note, Amish attempts to manage sexual and domestic abuse internally within the church rather than turn to outside authorities is a sad story that we recognize in many of the groups we study_though scholars of “mainstream” religion could say the same.

It is hard to find omissions within a book as carefully researched and crafted as The Amish, and to beg for greater treatment of one or another theme seems absurd: I can certainly imagine the look on my editor's face if I asked for just a few thousand more words to cover topic $\mathrm{X}$ or $\mathrm{Y}$ in a book already 500 pages long! But I would be remiss if I did not note one significant issue that I wish the authors had more directly considered. Given the insular nature of the Amish and their desire to maintain separation and privacy, I would have appreciated greater discussion of the authors' own navigation of these waters. For example, they briefly discuss Amish aversion to photographs (104), a mere two pages after a photograph of smiling Amish children! The Amish preference for privacy seems to push up against researchers' need to access and assess.

Certainly those of us studying other alternative or new religions encounter the same issues, and it would have been beneficial to hear how these scholars navigated similar waters.

\section{Bibliography}

For details on any of the new religions mentioned in this essay, see:

Bromley, David (ed.). 2014. World Religions \& Spirituality Project. (www.has.vcu.edu/wrs/).

Chryssides, George, and Benjamin Zeller. (eds.). 2014. The Bloomsbury Companion to New Religious Movements. London, U.K.: Bloomsbury.

Lippmann, Walter. 1929. A Preface to Morals. New York, NY: Macmillan Company.

Moore, R. Laurence. Religious Outsiders and the Making of Americans. New York, NY: Oxford University Press

Shipps, Jan. 1987. Mormonism: The Story of a New Religious Tradition. Urbana, IL: University of Illinois Press.

Stein, Stephen J. 1992. The Shaker Experience in America: A History of the United Society of Believers. New Haven, CT: Yale University Press. 


\section{Review of The Amish by an Amishman}

Tom Coletti

Farmer

New Order Amish Church

Union Grove, NC

\section{A View from the Inside}

The book The Amish is a major undertaking. To treat a topic about the Amish may seem easy if we think we are dealing with a unified group that looks and lives the same way. As we learn more about the subject, as the book points out, we see that there are many differences, some minor and some major, when we examine the people called "the Amish."

My task in writing this paper is a humbling experience. As a baptized member of the Amish Church, I will try my best to give a "view from the inside."

There is so much good information included in this book. The authors' treatment of the historical and religious roots of the Amish is excellent. I would recommend these chapters to our own people who are interested in knowing more about our faith. Sometimes it is good to hear what others have to say about the things and ideas that we can take for granted. The authors examine the Amish in a kind way and present us in the best light. There is no "Amish bashing" as is sometimes found in writings by ex-Amish or spiritual writers who criticize us if we don't explain out faith as they think we should.

The authors are fair in their treatment of the Amish which is a credit to their scholarship. On page 383 they make a humble admission that even scholars have their biases. They write “...hundreds of scholars and practitioners serving the Amish people who despite their commitment to impartiality and detachment... bring their own assumptions and biases.” Writing about themselves, the authors go on to state "...we too may be offering a lopsided view of Amish life.” I would not call the book "lopsided.”

Looking at the book from the "inside," one lack that is apparent is that the authors are not of our faith. They examine the Amish from an historical, sociological, and anthropological point of view. We have no right to ask more of a person than what they have to give. However, a view from the inside would not be complete without stating that our Amish religion is a faith reality. What makes us Amish is not our lifestyle but our faith. The form our lives take, which is part of our salvation, is a result of an attempt and a decision, developed over the centuries, to live as followers of Jesus. The German term Nachfolger Christi is one we hear often in our preaching.

Two terms that are used throughout the book are "nonconformity to the world" and "separation from the world." These statements from the New Testament are foundational to the Amish faith. 
Nonconformity is found in Romans 12:2, "Und stellet euch nicht dieser Welt gleich." Separation is found in II Corinthians 6:17 "Darum gehet aus von ihnen und sondert euch ab." We often hear about "absonderung von die Welt." These words are in effect a joining together of the above two Scriptures.

The authors also use the term Gelassenheit to explain the life walk and faith of the Amish. All three words, nonconformity, separation, and Gelassenheit, are important terms in understanding the Amish. Using these terms interchangeably can cloud some important distinctions. Often in the book, Gelassenheit is used to explain what I would call nonconformity. "Separation from the world" is sometimes explained as nonconformity (page 72 and 73). To try to point out some subtle yet important differences, I would like to examine each term on its own.

First, "to be non-conformed" comes from the Greek word that in Strong's Concordance (\#4964) is explained: "This word could not be used of inward transformation... [it] stresses outward conformity..." "Nonconformity" is well used to explain the outward form that our Amish life takes. The clothes we wear, the technology we accept or reject, out homes and the businesses we own are all part of our "nonconformity."

"Separation (Strong's \#873) from the world" has to do with the Amish practice of not following the thinking and actions of the world. We sing in Hymn \# 393 in the Ausbund, "Auf diesem Weg hal ich drei Feind...Der Teufel und die Welt dazee mein eigen Fleish und Blut." We see the way of the world as an enemy to our walk as followers of Christ. We see the world as part of an evil system which we are in but are not to be a part of. Our forefathers rejected the world before they developed a "form" that made us "non-conformed" people.

Having made a distinction between "nonconformity" and "separation," we observe that these distinctions are not made by the authors. There is also a "bias" presented that the more nonconformed a person is the more Amish he is.

From the inside, we observe evidences that some very "non-conformed" groups are in some ways not "separate" from the world that we consider as our enemy. When cultural forms lack the spirit of separation, we can see evidences of worldliness. For example, in some very low groups the person banned is treated like someone who is thrown out of the club rather than someone who is being urged to return to the fold. Regular and close relationships with worldly neighbors can be practiced by even very low Amish groups.

The authors treat "bed courtship" and do not say that it is practiced by the lowest groups. They compare it to driving a car or dressing like the English (pg. 413). Those groups that strive for spiritual separation would maintain that bed courtship is a strong temptation of the flesh. Our authors treat bed courtship in too innocent a light by saying that "a couple spends much of the night together in bed, clothed, ostensibly without sexual relations." They do not say that the "...fewer than ten percent of Amish..." that practice bed courtship is from the lowest groups. They seem to keep the situations that could be seen as negative anonymous by saying "some 
groups” or “some couples” (pg. 222). They don’t hesitate to make the distinction when speaking of buggies, houses, types of farming, etc. This selective way of identifying some groups and keeping other groups anonymous seems to contribute to the bias that the "true" Amish are the most non-conformed.

We now look at the word Gelassenheit. It has taken on a special meaning when it is used to describe Amish spiritually. When Chapter Five of Matthew's Gospel is read in church we sing hymn number 623 in the Ausbund. The hymn uses Glassen and Gelassenheit to explain being "poor in spirit." Used in this way, Gelassenheit is a deeply spiritual word that goes deeper than the "form" our lives take. It reflects the spirit of uff geva as we say in Pennsylvania Dutch. It reflects our relationship with God, with our brother and with the Church. It calls us to have the mind of Jesus as we read in Philippians 2:5-8.

Figure 6:1 on page 99 — the "Five Dimensions of Gelassenheit" — weakens the spiritual meaning of the word when it is used to describe symbols of dress, horse and buggy, and our German dialect. The implication of the diagram fails to make the proper distinctions between nonconformity, separation, and Gelassenheit and further supports the "bias" that we have been writing about.

I need to say at this point that I am not implying that we can separate our life and ethics from our salvation. When that is done as, we see what happens from those who historically became the most liberal of Mennonite groups. The faith of our common forefathers has been lost. The so-called "two track" system has taken its adherents into worldly religions. Our spirituality has to be Amish in nature to remain Amish in form.

It must also be said that without external "nonconformity" one cannot maintain a life of "separation" from the world. The authors treat this situation well on page 413 and 414 when they tell of the Millers coming out of the Amish box. Mrs. Miller is quoted as saying, "We're not trying to throw everything away...” If they are not throwing everything away, the one thing they have given up is being Amish.

My purpose in writing so many words separating three basic terms that in the final analysis should not be separated is to continue to point out the "bias" that implies: "The more non-conformed a group is, the more Amish it is.”

In the preface the authors state, "We are loath to use the labels traditional and progressive." Though they are "loath" to use the labels, they begin to set forth the bias that says the more non-conformed a group is the more "Amish" they are. As we have written, this bias is supported by not making the proper distinctions between nonconformity, separation, and Gelassenheit.

The "bias" is seen in most of the photographs in the book. Pictures of the "traditional" Amish are shown next to the "progressive” Amish. Although the text makes some distinctions, 
the picture's subtitles give the impression that most real Amish are the traditional ones. One obvious photo is of an Amish buggy (pg. 46) with battery lights. The subtitle under the picture states, "most traditional groups do not have electric lights." The fact is that most Amish groups use battery lights and very few groups shun SMV emblems.

The bias really blooms in Chapter Fifteen, “Agriculture.” It is a true statement that prior to 1950 most Amish were farmers (page 276). The picture on page 280 gives the impression that most Amish milk by hand and ship milk in cans. The fact is that many groups who milked by hand have given up milking.

Another implication is that only the progressive Amish make use of non-Amish veterinarians and use fertilizer and pesticides (page 283). Many of the Amish who continue to milk cows are from the groups that the authors consider "progressive."

In treating organic farming, the authors do not mention that most of the Amish who practice organic farming are those whom the authors consider progressive. The Green Field Farm and Lancaster Farm Fresh Co-operative would include these so-called progressives.

In addition to organic farming, intense grazing and ecological sustainability are treated in a very positive light. However in stating that “... even though Amish farm technology and practice are not driven by environmental concerns, Amish values and way of life tend to mitigate environmental harm," the authors do not mention that those who do practice environmental means are not the most traditional but those labeled progressive. That would include my good friend David Kline.

Our forefathers chose to separate themselves from the world. Their desire was to restore the New Testament Church. Their faith led them to a way of life that supported their faith. No matter how non-conformed a group is, if it loses its separation it ceases to be Amish in faith and becomes merely a culture. I realize that for sociologists and anthropologists it is easier to examine a culture than to examine a faith. I have written before, I do not have the right to critique our authors for not moving outside of their expertise. Perhaps a "view from the inside" that I have written is unfair to this monumental work on the Amish. Where I have written unfairly, I ask forgiveness.

To end on a more positive note, I will say that the chapters on "Who Are the Amish," "Religious Roots," and the "The Amish Way” in particular are very well done. There is also so much good information written about the Amish throughout the book. The book The Amish will fulfill a service to people who are interested in the Amish. I am reminded of a woman who said to me that, "I love the Amish. I read everything I can about them." Then she went on to say that she reads Beverly Lewis and Wanda Brunstetter. How much better for her would it be if she would read Kraybill, Johnson-Weiner, and Nolt if she really wants to know about the Amish.

The section "Chaste Romantics” in the chapter "Amish in Print” is a very important 
section. It should be required reading for any Amish bookstore owner who sells the so-called "bonnet novels." The authors have done well in exposing these prolific writers as “...largely evangelical Christian women writing for evangelical readers.” They describe the books as containing, “...an inspiring evangelical message of personal faith in Jesus... and in some cases a critique of Amish faith.” These books are not for Amish readers. They are more dangerous to the faith than books that mock or disdain the Amish way. These "bonnet novels" criticize the very religious belief of the Amish. By saying that Amish people are not truly Christians unless they have an evangelical style "born again" conversion experience, they promote the theology behind many who have left the Amish. A temptation to embrace a different religious explanation for one's faith can do more to destroy Amish faith than embracing more technology. Our forefathers embraced the faith and developed a form of life to support that faith. Keeping the faith is the key to remaining Amish.

I have enjoyed studying this book and commend the authors for the scholarship and research that produced this book. It is a book worthy to be read by any Amishman.

In closing I would like to say that I do not wish to be understood as not being in favor of nonconformity. I feel that all Amish can learn from churches that are "lower" than they are. We must avoid the thinking that says, "Any church that has gone higher than we have has gone too far, and any church that is lower than we are has not come far enough.” We need to keep our nonconformity and out separation in balance in the spirit of Gelassenheit.

Nix für ungut. 


\section{Authors' Reply to the Reviewers ${ }^{a}$}

Donald Kraybill

Professor

Young Center for Anabaptist and Pietist Studies

Elizabethtown College

Karen Johnson-Weiner

Professor

Department of Anthropology

State University of New York, Potsdam

Steven Nolt

Professor

Department of History

Goshen College

We are grateful to the editors of JAPAS for arranging this symposium between three commentators and ourselves. We also acknowledge the many kind words that the commentators offered about our work and scholarship in The Amish. We appreciate their gracious affirmations on our ten-year project.

Each of us contributed to this unified response. We address some but not all of the issues raised by the commentators. All of them offered suggestions for additional topics. Our target audience for the book was threefold: scholars, students (enrolled in academic courses), and the general public. Although we wanted our coverage of Amish communities to be thorough, we did not envision it to be encyclopedic or comprehensive. We had to be selective about which topics we could include in a 500 page book. As we note in the Preface (xii), we selected the issues we considered most "salient to our argument." We often remarked among ourselves as we wrote that we had enough sources and content to write a complete book on the theme of each chapter of The Amish. And indeed we did!

We address the concerns of each commentator one by one.

\section{Reply to Steven Reschly}

Reschly would like more attention to European and American history. We were not constrained by an editor or publisher regarding how much historical material to include or where

\footnotetext{
${ }^{a}$ At the time of response, the authors did not know the identities of reviewers. For reader ease, reviewer names and gender specific pronouns supplement text the authors originally left generic.
} 
in the narrative, but we did make choices about what we thought would be most helpful for our target audiences to understand the Amish world of the twentieth and twenty-first centuries. Along the way we tried to situate the Amish story in wider and deeper historical currents. For example, we place the emergence of the old order movement squarely in the context of what social historians have called "the refinement of America" and the economic and cultural implications of the market revolution. We did not present the old order movement as springing solely from internal Amish ecclesial debates, as did Paton Yoder. Similarly, we drew on the work of historian Ronald Kline to contextualize Amish responses to technology in the context of rural American consumerism more generally. Had this been primarily a work of history, we could have engaged historiography in a systematic way.

The second issue Reschly raises involves our use of theory. We are completely baffled by his words that we "borrowed theoretical models" used by Trollinger in her book on tourism and Weaver-Zercher in her book on romance novels. This is not correct. Kraybill was the series editor for both of those books. In our judgment Trollinger does not employ an overarching theoretical model for her work. If there was any borrowing, the trail in fact goes in the opposite direction than Reschly implies. In chapter 1 Trollinger cites Kraybill's work in The Riddle of Amish Culture 19 times and frequently in later chapters. We were grateful that Valerie WeaverZercher in several conversations alerted us to Lipovetsky's work on hypermodernity. We did incorporate his notion of speed as one of several dimensions of modernity in our larger conceptual model.

Reschly dislikes our central conceptual framework-negotiating with modernity-yet confesses that he has no alternative to suggest. We like the midcentury social psychologist Kurt Lewin's dictum that "there is nothing so practical as a good theory.” We think negotiating with modernity provides a strong conceptual framework for understanding Amish studies. We leaned on Kraybill's original use of this theoretical perspective in his first edition of The Riddle of Amish Culture in 1989. Contrary to Reschly, we think it is possible to operationalize and specify exactly what we mean by modernity with concepts such as specialization, separation of time and space, diversity, rationality, individualism, abstraction, choice, liquidity, and speed. Indeed, some of the most important social theorists of our time, such as Anthony Giddens, have used concepts of modernity and late modernity to great effect.

Moreover we think “negotiating with modernity” provides a powerful analytical tool for understanding dynamic social change inside the Amish community and in the community's interaction with the larger culture. We employ the negotiation model at two levels: explicit and implicit.

We disagree with Reschly’s statement that, "negotiation is too self-conscious and calculating” to use it to analyze Amish interactions with the outside world. For example, since the formation of the National Steering Committee in 1967 (which represents many Amish groups) this group explicitly engages in self-conscious and deliberate negotiations with 
government officials at the local, regional, state, and federal levels. We also think the "negotiation" model offers a penetrating lens to interpret many of the deeper implicit cultural patterns of Amish life: riding in a car but not owning one, using pneumatic and hydraulic power instead of electricity to operate sizable machine shops, leaving the farm but not vacating rural life, terminating education at the eighth-grade, yet tapping the resources of outside professionals. There are abundant examples of both implicit and explicit negotiation in Amish life.

Although we view "negotiating with modernity" as a powerful explanatory concept, it does not have the predictive power required for a good scientific theory. Its inability to predict future behavior is intrinsic to the negotiation model itself for in Amish society specific outcomes are always tenuous, dynamic, and uncertain. Yet these very characteristics indeed describe the nature of many of the consequences of the Amish interface with contemporary society.

Additionally, we are bewildered by Reschly’s bewilderment when he says “the Ordnung process... [is] impossible to explain, but if one understands it or has experienced it no explanation is required." We do not think it's a contradiction or cognitive inconsistency to hold two ideas at the same time which may, on the surface, appear conflicting. There is nothing particularly mysterious about the fact that Amish people may have an intuitive fear about how technology might dramatically change their community, even though they're not exactly sure how the technology would change them. Nonetheless, they take strategic and rational steps to mitigate its possible threat to their community.

Finally, Reschly offers very good suggestions for linking Amish studies more directly to other fields of scholarship beyond the Anabaptist world. While beyond the scope of The Amish, they are certainly of interest to Amish studies, and we applaud these suggestions as excellent projects for future research.

\section{Reply to Benjamin Zeller}

Zeller provides a number of interesting parallels between the nature of Amish society and New Religious Movements (NRMs). These parallels involve not only their internal organization but also their critique and caution about the modern world. We agree with Zeller that the definition of "mainstream" culture-which both the NRMs and Amish oppose-is problematic. One way to clarify what we mean by mainstream is to conceptualize it on several levels: popular culture articulated by the media; regional culture; and local culture. Nevertheless, this risks homogenizing hundreds of diverse subgroups in American society into a bland social unity. Yet, despite the — often hidden — diversity of the “mainstream," there are persistent and salient national themes such as individualism and achievement that are pervasive.

Zeller would like more information about how we navigate the delicate waters between Amish preferences for privacy and our need as scholars for access. To address this completely with helpful examples might require another book! This is certainly an interesting and complicated issue, and, in retrospect, we could have included an appendix on methods in which 
we would have addressed how each of us negotiates between these two conflicting interests. Kraybill explored some of these dilemmas previously in a chapter "Amish Informants: Mediating Humility and Publicity" that appeared in The Amish and the State (edited by Zimmerman-Umble and Weaver-Zercher, 2008).

\section{Reply to Tom Coletti}

Coletti makes a distinction between "nonconformity" and "separation" based on theological distinctions in Strong's Concordance. Coletti understands nonconformity as the outward forms of Amish faith expressed in practices related to clothing and technology. By contrast separation, for him, refers to an inward spirit of rejecting the "thinking and actions of the world." Coletti contends that "the spirit of separation" produces outward cultural forms of nonconformity. We do mingle our use of the words nonconformity and separation in the text. We're still not sure there is as sharp a distinction between these two terms as Coletti suggests. We would need more discussion with him to persuade us that there is a clear distinction between these two ideas. Regardless of the specific words, we certainly agree with Coletti that in any religious group, not just the Amish, it is possible for cultural forms and traditions to become lifeless and lose their original spiritual intent.

Coletti questions our use of the word Gelassenheit. We use this concept in two ways to refer to: 1) an inner spiritual submission and yieldedness to God; and 2) the outward cultural forms that reflect the inner spiritual submission. These two dimensions cannot be easily separated. We disagree with Coletti that the illustration on page 99 diminishes the spiritual meaning of Gelassenheit. In fact we devote several paragraphs to the spiritual dimensions of Gelassenheit (64-66). Moreover much of our understandings about the external expressions of Gelassenheit are indebted to the writings of a New Order Amish Deacon in Ohio whom we cite on page 98 preceding the figure. In summary, we understand Gelassenheit to have both an inner spiritual reality and an external social one.

Coletti raises a final concern about bias and the "real” Amish. He perceives a bias throughout our text that implies that the "real" Amish are the most traditional ones. To begin we summarize our intentions. We never intended to make value judgments about which Amish groups or individuals were the best or worst, genuine or pseudo, real or artificial, most or least spiritual.

In fact in chapter 1 , we devote an entire section (12-15) to "Searching for the 'Real' Amish.” We give specific examples of high and low Amish groups and argue that all of these affiliations are real Amish. Another one of our intentions in writing the book was to describe a variety of Amish groups including low Ordnung ones, which are frequently overlooked in scholarly research and writing. We do not apologize for including them in the book, but we certainly did not intend to convey the impression that their Amishness is better or more authentic than change-minded groups. In fact we argue that Amish identity is fluid and changing. Thus the 
more progress-minded Amish, who are more assimilated into modern life, are also "real” Amish in our minds. Despite our good intentions, it's possible that a positive bias toward the more traditional groups somehow slipped in to our story unawares because all of us are blind to our own biases.

Yet we would challenge some of the evidence that Coletti provides to document our bias. For example, we think our caption under the photo of the horse and carriage on page 46 is a statement of fact that does not reveal any bias. We do not say that it is good or bad to have battery-powered lights versus lanterns on buggies. Coletti says the "bias is seen in most of the photographs in the book" [emphasis added]. We tried to be evenhanded with photos by using ones of traditional affiliations and progressive ones. On some occasions we displayed them sideby-side (106-07, 144). Coletti claims that "the bias really blooms in the chapter on agriculture." Under the illustration of a young woman in a milk house with a large bulk tank (280) we state that "vacuum milkers and bulk tanks were often controversial in Amish settlements" [emphasis added]. We also state that the most traditional farmers continue to milk by hand. Coletti says this caption gives the impression "that most Amish milk by hand and ship milk in cans." We did not say that, nor did we make a judgment, about which type of milking is better or worse. We do not understand how the photo or the caption suggests a bias toward hand or machine milking. We are very aware of the changes in some communities regarding milking and agree with Coletti, "that many groups who milk by hand have given up milking." Yet that fact does not pertain to the illustration or the content of the caption.

In these cases and in other captions we tried to provide a factual description without any bias. We fail to understand how the illustrations and their captions show evidence of our bias in favor of traditional groups or any group for that matter.

We heartily agree with Coletti that if an Anabaptist church loses its inner spirit of submission to God and conviction to follow the way of Jesus, its cultural forms can easily become lifeless and hollow. Continuing to have cultural forms that are infused with a genuine warm spirituality is a challenge to all who profess a Christian faith, including the diverse Amish church communities.

Once again, we thank Reschly, Zeller, and Coletti for their thoughtful comments, suggestions, and criticisms and for taking the time to scrutinize our text. 